\title{
MEASUREMENT OF HUMAN CAPITAL AND MARKET VALUE OF LISTED COMPANIES
}

\author{
Joanna Żarnik-Żuławska \\ Nicolaus Copernicus University in Toruń, Toruń, Poland \\ e-mail: j.zarnik@interia.pl
}

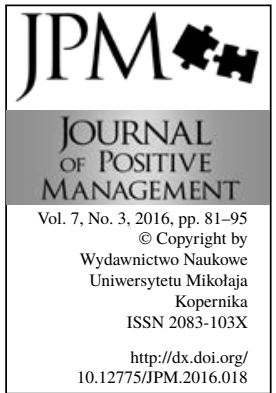

\begin{abstract}
Current analysis indicates gap between the market value and the book value of the largest international enterprises. Uncountable assets such as, intellectual capital and related to human capital have more and more meaning for a company's market value increase. This paper studies the relationship between market value and approach to human capital measurement. In article indicated that decrease of intellectual capital value is an unfavourable phenomenon and leads to company stagnation, in parallel its increase generates the developmental potential of the company. Research doesn't show what percent of the decisions related to financial investments were made dependent on the human capital in the company. However the paper shows that interest of shareholders and investors in intangible assets and human capital measurement is more often observed with in the last few years.
\end{abstract}

Keywords: intellectual capital, human capital, market value, book value, indicators, uncountable assets, human capital measurement

Paper type: Conceptual paper

\section{Introduction}

Many companies recognize that the gap between the market value and the book value becomes more significant. The market value exceeds the book value, and the value of the capital invested in the company exceeds the costs of assets replacement. Only 20 years ago global companies had their market value at a level similar to the value of their countable assets, which corresponded to the Tobin's Q indicator of around 1 (Jarugowa and Fijałkowska, 2002). Currently in the leading companies, such as Microsoft, the Tobin's Q indicator is around 2, which means that $100 \%$ of the company's market value is made of uncountable assets that include, among others, the intellectual capital and related to the human capital [1]. Hence, the intellectual capital constitutes a significant element of the company's market value, and due to this its position should be calculated and presented as an indicator of the total value of a company. Information arising from 
MEASUREMENT OF HUMAN CAPITAL

Joanna Żarnik-Żuławska the intellectual capital measurement can encourage investors to future investment and play a crucial role in forming the market value of a company.

The author attempted to indicate the connection between the increasing market value of the largest companies and a need for measuring the intellectual and human capital. At the same time pointed out that there are still difficulties associated with the measurement of human capital. Regardless of these difficulties, more and more companies measure of human capital. Results of own research confirmed this and showed of measurement range in Polish listed companies. In order to obtain the data used indirect survey. Survey conducted in 50 Polish listed companies in the period September 2015-February 2016. The rest of the paper shows specific examples of using information regarding human capital to predict and create the company's market value.

\section{A gap between the market value and the book value of companies as a stimulus for the intellectual capital measurement}

Two indicators are most often used to estimate the company's intellectual capital: indicator of relations between the market value and the book value MV/ BV and Tobin's Q indicator. Both of them give opportunity to estimate the intellectual capital of any company, to track changes in its value or to compare its value to the value of any other company. D. Appenzeller observed that those indicators have significant limitations for example the company's market value depends on many factors such as: financial condition, intellectual capital or a situation on the market. Thus, in bull market period, when share prices are rising, a high level of both indicators can be expected, and it does not have to be an evidence for high level of intellectual capital. While in a bear market periods, the company's market value - and as a result its intellectual capital - will be reduced (Appenzeller, 2009). Table 1 shows the market value and the assets value of the largest global companies in 2016. The discrepancy between the market value and book value is also noted by the Polish companies, e.g. LPP (5.4), CCC (7.8), PKN Orlen (1.5) [2]. Table 2 shows the market value and book value of the largest companies listed on Warsaw Stock Exchange.

Despite a wide range of literature, there is still lack one definition of the intellectual capital term. According to L. Edvinsson the intellectual capital is a difference between the market value and the book value of an organization, in other words it is a sum of hidden assets, not included in the company's balance sheet (Edvinsson and Sullivan, 1996). The concept of L. Edvinsson shows two basic elements of the intellectual capital, that is human capital and structural capital. The human capital includes the knowledge, skills, experience, attitude (e.g. dedication, ability to learn, will to share the knowledge and ideas, etc.). The structural capital is an ability to support the employees' efficiency by the organisation. It includes the tools and systems assisting the transfer of knowledge 
(organizational capital) and relations with clients (client capital) (Mouritsen and Larsen, 2001). Estimation the intellectual capital value is important, but even more important is predict its higher and lower level. Forecasting human capital level creates a real ability to effectively manage and making comparisons the company's market values by the investors.

\begin{tabular}{|c|c|c|c|c|c|}
\hline No. & Company & Country & $\begin{array}{l}\text { Tangible } \\
\text { assets }\end{array}$ & $\begin{array}{l}\text { Market } \\
\text { value }\end{array}$ & $\begin{array}{l}\text { The ratio of } \\
\text { market value to } \\
\text { tangible assets }\end{array}$ \\
\hline 1 & Apple & United States & 293 & 586 & 2.0 \\
\hline 2 & Alphabet & United States & 149 & 500 & 3.4 \\
\hline 3 & Microsoft & United States & 181 & 407 & 2.2 \\
\hline 4 & ExxonMobil & United States & 336 & 363 & 1.1 \\
\hline 5 & Berkshire Hathaway & United States & 561 & 360 & 0.6 \\
\hline 6 & Facebook & United States & 49 & 314 & 6.4 \\
\hline 7 & Johnson \& Johnson & United States & 133 & 312 & 2.3 \\
\hline 8 & Amazon.com & United States & 67 & 292 & 4.4 \\
\hline 9 & General Electric & United States & 492 & 285 & 0.6 \\
\hline 10 & China Mobile & China & 219 & 241 & 1.1 \\
\hline 11 & Nestle & Switzerland & 123 & 235 & 1.9 \\
\hline 12 & AT\&T & United States & 402 & 234 & 0.6 \\
\hline 13 & Roche Holding & Switzerland & 75 & 222 & 3.0 \\
\hline 14 & Procter \& Gamble & United States & 129 & 218 & 1.7 \\
\hline 15 & Wal-Mart Stores & United States & 199 & 215 & 1.1 \\
\hline 16 & Royal Dutch Shell & Netherlands & 340 & 210 & 0.6 \\
\hline 17 & Verizon Communications & United States & 244 & 206 & 0.8 \\
\hline 18 & Pfizer & United States & 167 & 205 & 1.2 \\
\hline 19 & Anheuser-Busch InBev & Belgium & 136 & 204 & 1.5 \\
\hline 20 & PetroChina & China & 368 & 203 & 0.6 \\
\hline 21 & Novartis & Switzerland & 131 & 203 & 1.5 \\
\hline 22 & Alibaba & China & 56 & 200 & 3.6 \\
\hline 23 & Coca-Cola & United States & 91 & 192 & 2.1 \\
\hline 24 & Chevron & United States & 266 & 192 & 0.7 \\
\hline 25 & Visa & United States & 54 & 189 & 3.5 \\
\hline 26 & Home Depot & United States & 42 & 169 & 4.0 \\
\hline 27 & Walt Disney & United States & 90 & 169 & 1.9 \\
\hline 28 & Oracle & United States & 104 & 168 & 1.6 \\
\hline 29 & Samsung Electronics & South Korea & 206 & 161 & 0.8 \\
\hline 30 & Intel & United States & 105 & 149 & 1.4 \\
\hline
\end{tabular}

MEASUREMENT OF HUMAN CAPITAL

Joanna Żarnik-Żuławska

Table 1. Market value and tangible assets of the largest global companies in 2016 (situation on 27.12 in millions of USD)

Source: Forbes, Global 2000 World's

Top Companies 2016, www.forbes. com/global2000/. 
MEASUREMENT OF HUMAN

CAPITAL

Joanna Żarnik-Żuławska

Table 2. Market value and book value of companies listed in WIG 20 index of the Warsaw Stock Exchange (situation on 27.12 in millions of PLN)

Source: Own work based on the data available on stock exchanges in Warsaw, www. gpw.pl/spolki_z_ indeksu_wig20.
The market values of companies indicated in table 1 were determined for the largest global companies in 2016 when, among other things, as a result of Brexit a sell off of shares was observed on the London Stock Exchange as well as some unrest of the investors due to the results of the election in US. Additionally, current analysis of the subject indicates decreasing share of investment in tangible assets with the simultaneous increased interest in non-tangible assets. This is confirmed by, among other things, an annual report of the most valued global brands, which indicates that one of factors not taken under consideration in financial statements, but at the same time generating the market value is intellectual and human capital of the company [3].

\begin{tabular}{rlrrc}
\hline No. & Company & Market value & Book value & $\begin{array}{c}\text { The ratio of market } \\
\text { value to book value }\end{array}$ \\
\hline 1 & CCC S.A. & 7766.89 & 992.10 & 7.83 \\
\hline 2 & EUROCASH & 5376.07 & 1046.94 & 5.14 \\
\hline 3 & LPP & 10355.12 & 1912.98 & 5.41 \\
\hline 4 & PGE & 19632.49 & 40989.00 & 0.48 \\
\hline 5 & TAURONPE & 5134.97 & 16348.99 & 0.31 \\
\hline 6 & ENEA & 4392.35 & 11999.47 & 0.37 \\
\hline 7 & ENERGA & 3871.53 & 8685.00 & 0.45 \\
\hline 8 & CYFRPLSAT & 15528.18 & 10947.40 & 1.42 \\
\hline 9 & ASSECOPOL & 4440.52 & 5388.20 & 0.82 \\
\hline 10 & ORANGEPL & 6942.37 & 11816.00 & 0.59 \\
\hline 11 & KGHM & 18400.00 & 20529.00 & 0.90 \\
\hline 12 & PGNIG & 32391.00 & 31162.00 & 1.04 \\
\hline 13 & ALIOR & 7003.19 & 5876.62 & 1.19 \\
\hline 14 & MBANK & 13867.88 & 12935.29 & 1.07 \\
\hline 15 & PEKAO & 32651.27 & 22724.47 & 1.44 \\
\hline 16 & PKOBP & 34987.50 & 32336.66 & 1.08 \\
\hline 17 & BZWBK & 31293.61 & 19658.00 & 1.59 \\
\hline 18 & PZU & 28021.32 & 12376.72 & 2.26 \\
\hline 19 & LOTOS & 7145.36 & 8517.34 & 0.84 \\
\hline 20 & PKNORLEN & 36971.17 & 24860.00 & 1.49 \\
\hline & & & & \\
\hline
\end{tabular}

The book value of a company is calculated based on the company's balance sheet items (assets and liabilities). It does not always show the real net value due to using simplified forms of tangible assets estimation (depreciation, remission of fixed assets, valuation of securities). The gap between the book value and market value of a company has been increasing continuously for at least two decades. For 
example, in 1992 for the American companies listed on the Stock Exchange it was $40 \%$. Those data are also confirmed by the studies regarding the value of takeovers. The proportion of transaction price to the book value was 4.4 (Wachowiak, 2005).

The intellectual capital measurement, and especially the human capital, is connected with some reluctance for the capital management ethicists as well as with many serious methodological difficulties. Nonetheless, the growing difference between the market value and book value of a company shows that the intellectual capital constitutes a significant part of the company's market value, and its position should be measured and known. Such approach prompts companies to continue the works connected with development of optimal measurement and valuation methods for the intellectual and human capital. The need for measuring the human capital also results from progress of the function of personal controlling, which in the recent years has become an important source of information when making crucial decisions. More and more companies become aware that increasing the value of human capital is of great importance for rising the value of the whole company. As noticed by A. Lipka, an accrued measurement of the human capital gains importance as another, and maybe the most important part of the data base of the company in battle with competitors (Lipka, 2010). It also allows to evaluate the current personal strategy and monitor the progress in achieving goals regarding human resource management.

\section{Meaning of the measurement of human capital in difficulties it entails}

Increasing the financial capital was the most important tasks of the managing directors so far. However, in the modern world innovations, intellectual capital and its integral part - human capital, have become key factors of the companies' development. It was influenced by, among other things, studies conducted by Bontis, and Fitzenz, who proved that the human capital directly influences the value of the intellectual capital, which, on the other hand, generates better results of the company (Bontis and Fitzenz, 2002). That is why much more attention is now paid to non-tangible assets, including the human capital and properly inform the investors about its value in the company. Increasingly, attention is drawn to the fact that the economic growth is more caused by non-tangible capital than fixed assets [4]. That is why World Economic Forum and organisations such as OECD (Organisation for Economic Co-operation and Development) carry out works connected with the development of methodology of measuring the human capital. The measurement of traditional, exclusively economic aspects related to commercial or financial activities of the company is not sufficient. The changes in the quality of managing the human capital are today one of the main reasons for the increase productivity and economic growth (Nakumara, 2000).

On the one hand there is increasing interest estimating the value of human capital on the other hand, it is still a lot doubts in this issues. One of them 
MEASUREMENT OF HUMAN CAPITAL

Joanna Żarnik-Żuławska concerns the commonly used accounting systems, which take into account the profit generated mainly by the tangible capital (financial, material). Conventional accounting systems are not siutable to measuring and strategic human capital managing. They often classify the expenses incurred for non-tangible assets (including the human capital) as costs and not as investments (contrary to expenses for buildings and machines). Moreover, in connection with the fact that the earnings of the most of managers depend on the company's profit, the deciding parties focused on a fast return from the investment often choose to invest into material assets and not the human capital (Becker et al., 2013).

Difficulties associated with human capital management arise from the essence of human resources [5]. The notion of human capital includes many components such as skills, professional experience, acquired knowledge, competencies or a level of motivation (Liu, 2014). Those individual components of human capital are in post parts immeasurable in a sense that they have no particular monetary value, thus it is not possible to express the human capital as a simple sum of its components (Rutkowska, 2012). Despite the lack of precision and reliability of human capital measurement, still it is possible to determine its general value, which is confirmed by numerous methods of the human capital estimation (Oxley and Trinh, 2008).

Secondly, the valuation of the human capital of an organisation is accompanied by some disagreements regarding the subject of the valuation. It can be understand as: individual capital, group capita or the human capital of the entire organisation (Lipka, 2010). Regardless of what is assumed as the subject of valuation, the important part of the measurement is to determine the relations between the people, the system of managing the human capital and the final effect for the company. It is the only way to show the influence of tasks undertaken by Human Recourses department on the company's result. It is also very important to determine the factors that by appropriate management construct the capital's potential, which is necessary to generate the economic value of the company. Therefore, it is important in measuring the human capital to include the cause effect relations, and most importantly to link causes and effect on the same analytical level (an employee, a team or a group, the whole company).

The measurement of the human capital is accompanied by problems connected with acquiring data. Some of the methods of valuating the human capital of a company are based on only economic variables (their acquisition is rather simple), others use variable of economic, psychological and organisational character. Unfortunately, the crucial decisions concerning the human capital are often made based on available but not very important data. Based on the available but not the most needed data, the company is not able to draw even general conclusions concerning cause - effect relations that occur in the organisation. Inappropriate understanding of such conclusions, on the other hand, may cause a falsification of the results of such measurement. The need for taking cause - effect 
relationships into consideration is another element that makes the measurement of the human capital very difficult. As an example, one may indicate here is attempt to evaluate the value of talent management program. The benefits this kind of program can be visible indirectly, even after several years. The human resources management, it is not about build value of company directly, in short time, but about changing particular components forming this value, usually in longer term. The thing that can be measured as a final effect often results from uncountable psychological or organizational aspects (Sierpińska, 2004).

Another challenge related to measurements of the human capital is hard to perform an appropriate interpretation based only on singular information or indicator, without knowing the wider context of the situation. For instance, the employees turnover indicator at $12 \%$ does not allow to determine whether such level is an issue for a particular company or not, until we compare such information with the level of employees turnover in other companies operating in a similar industry or historical data. It needs to be borne in mind that main goal is to measure the efficiency of company using their human capital and estimating the value of profits possible to obtain in the future. It is also important to analyse and assess the tendencies instead just state the facts. (Amstrong, 2006).

The information regarding the human capital and its management become a guideline for the assessment of general efficiency of the organisation and the point of interest for the shareholders and potential investors. The studies conducted by International Integrated Reporting Council (IIRC) in June 2016 show that more and more organisations conduct measurement of the human capital and provides investors with the information on their ability to create the company's value by effective human capital management [6]. Despite the lack of precision and reliability of the human capital measurement, monitoring actions concerning the human capital allows to obtain valuable conclusions and improve the decision making process.

\section{Scope of measurement of the human capital in the Polish listed companies}

The expectations related to Human Recourses department exceed beyond administrating the personnel matters and strive towards proving the value to internal and external customers.

Managing Directors more often declare a need for gathering data allowing them to evaluate the human capital and determine the relative input of the personnel function into long-term company development. Figure 1 shows the study results concerning the demand of the Polish companies for information about the human capital. The addressees of this survey were Presidents, Human Resources Managers, Directors, and others responsible for human resources management in the Polish listed companies. 
MEASUREMENT

OF HUMAN

CAPITAL

Joanna Żarnik-Żuławska

Figure 1. Demand for information regarding human capital (the opinion of representatives the Polish listed companies)

Source: Own work based on a survey conducted in 50 Polish listed companies in the period September 2015-February 2016.

Figure 2. Collecting data regarding the human capital in the Polish listed companies

Source: Own work based on a survey conducted in 50 Polish listed companies in the period September 2015-February 2016.

\section{8}

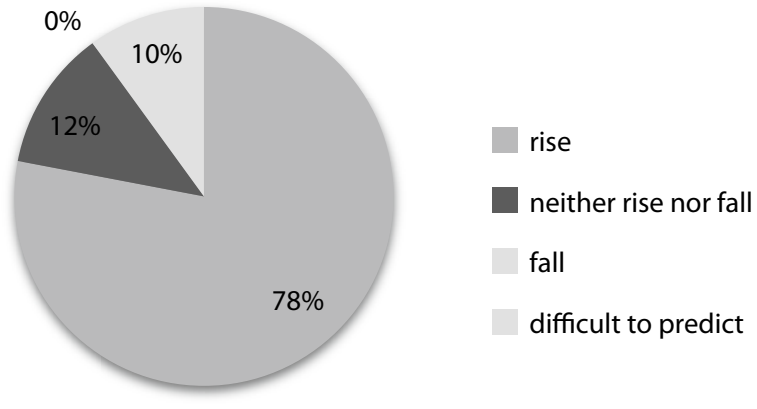

$78 \%$ companies indicated that the demand for information regarding human capital and its management will increase in the next three years. None of the respondents is expecting less interest of data regarding human capital in the future. Issues related to measuring the effects of the HR processes are still insufficiently explored and treated as a big challenge for many managers (Ward, 2008). There is a need to develop guidelines and procedures for implementation of measurements in HR management and to make attempts to identify and classify the major groups of indicators for personnel processes.

Proper use of the company's employee potential focused on the best customer service requires, among others, systematic monitoring of the skills and attitudes of employees. On the one hand, companies are increasingly dependent on the skills and competencies of the employees and their commitment, on the other, the employees themselves have an increasing openness to change their employers. This leads to the growth of fluctuations and the need to create systems enabling to maintain long-term relations between the company and employees. The interest of such measurement as, e.g. absence, fluctuation, satisfaction and engagement level, results of the employees, etc. is growing. $80 \%$ of the Polish listed companies indicated that their company collects data on human capital, $8 \%$ do not collect such data, and $12 \%$ is not able to determine whether their company collects information on human capital and/or its management. The scope of the collection of data regarding the management of the human capital in the Polish listed companies can be considered broad, it is presented in Figure 2.

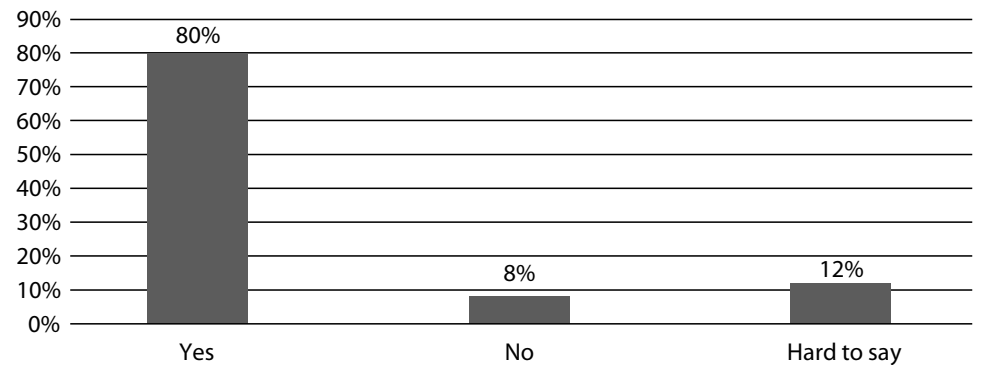


Collection data regarding human capital in the Polish listed companies can be considered as common. The scope of data is presented in Figure 2.

In the next part of the survey regarding human capital measurement there was question about issues related to the type of collected data. Among the measures used in human capital management companies usually gather personnel measures relating to the state and structure of employment, employment costs, employee absences, etc. Figure 3 presents the most commonly collected and used data on the human capital.

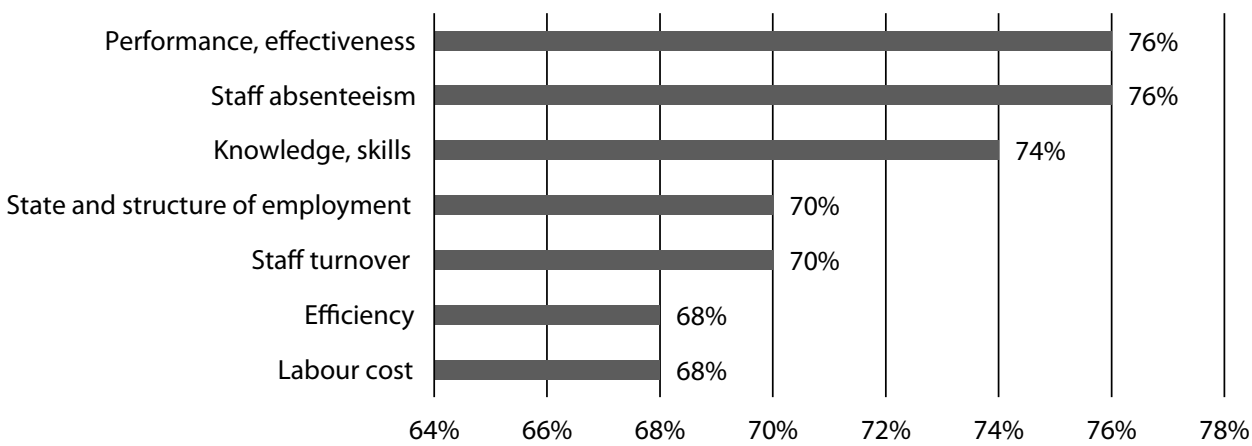

As many as $76 \%$ of companies monitor data on absenteeism. The same number of companies $(76 \%)$ collect data on the performance of employees, measurable results etc. $74 \%$ of companies collect data on the skills/knowledge, held training, etc. The least frequently the companies gather strategic measures (income from human capital, return on investment in human capital, human capital efficiency, etc.). Only $34 \%$ of companies collect data on the return on investment in human capital. At the same time $32 \%$ of companies declared that they do not collect such data.

The range of data regarding human capital accumulated by the Polish listed companies looks good compared with research conducted in the world with the participation of the 2500 personnel managers. Figure 4 shows data collected and used by HR departments in 65 countries.

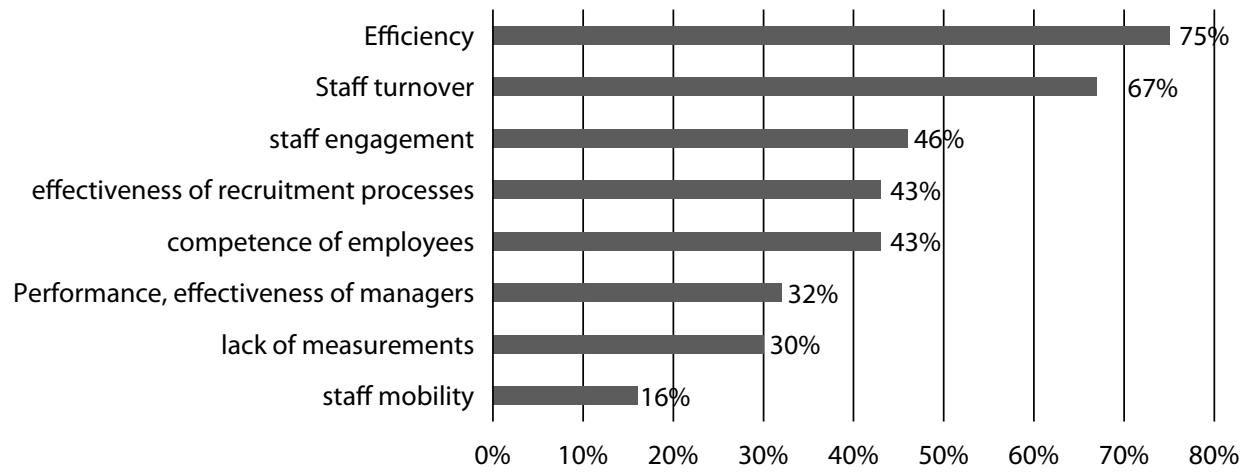

MEASUREMENT OF HUMAN CAPITAL

Joanna Żarnik-Żuławska

Figure 3. Data regarding human capital collected and used by the Polish listed companies

Source: Own work based on a survey conducted in 50 Polish listed companies in the period September 2015-February 2016.

Figure 4. Data regarding human capital collected and used by the HR departments in 65 countries

Source: Michael

Page company report - Globalny Barometr HR 2015, www. publikacje. michaelpage.pl/ globalny-barometrhr-2015. 
MEASUREMENT OF HUMAN CAPITAL

Joanna Żarnik-Żuławska
Among the declared measurement areas in the Polish and foreign companies, two common elements can be found: staff turnover and employee productivity. Encouraging is the fact that $70 \%$ of the Polish listed companies declared that they collect and use data on the employees' turnover, it is $3 \%$ more than in the all global companies. Performance of employees is measured in 68\% of the Polish companies listed on the Warsaw Stock Exchange and 75\% of global companies. The survey results indicate that Poland is focused primarily on measures of human resources (absenteeism, turnover, condition of employment structure). Meanwhile, the global companies often measure processes of the human capital management, e.g. the effectiveness of recruitment, mobility of employees. Thus data regarding human capital are collected relatively widely in both Polish and foreign companies. Whether, some scholars disclosed that many companies do not tend to reflect intellectual capital components in their balance sheets, even though they are trying to demonstrate them to potential investors. The result is a huge gap between the book value of the company and its market capitalization (Kaminska et al., 2014).

The study shows that in the Polish companies data on the human capital goes generally to the directors responsible for managing the company and it mainly concerns: employment costs, performance of employees, labour productivity, condition and structure of employment, turnover. The analysis shows that the companies collect data on revenues from the human capital and return on investment in the human capital, but 33\% of respondents admitted that they do not know who receives the data. Similar situation is with the data on the employee satisfaction, $28 \%$ of respondents did not know who receives the results of satisfaction survey and whether they are used for corrective action.

The presented results indicate the relatively small scope use of the strategic indicators in the Polish listed companies (personnel indicators are use quite often). This state encourages to further searching for solutions supporting the implementation of human capital measurements in the Polish listed companies in order to using this information to impact the company's market value.

\section{Examples of using the measurement of the intellectual and human capital to forecast and create the market value of a company}

Intellectual capital includes knowledge and skills, tools and processes supporting the performance of human resources. This means that two different companies with the same book value may have a completely different market value and opportunities for further development. It is no wonder that there is a growing interest in measuring the intellectual capital. An estimate of its value enables managing directors to evaluate current business strategy and to anticipate the consequences of actions taken. The decrease in the value of the intellectual capital is a negative phenomenon and promotes the crisis in the functioning of the 
company, while its growth may be identified with the development of company's potential. This is why the measurement of the intellectual capital gains crucial importance as the base information for shareholders and investors.

Recent trends have shown increase the importance of intellectual capital. Investors are looking for information on non-tangible assets and methods for estimating their value. In last years, they learned that intellectual capital valuation may constitute the basis to make money, but also to forecast the threat for listed companies. Some scholars discovered that if the value of the intellectual capital is lower than the average for the industry, the company is operating inefficiently and is exposed to crisis (Appenzeller, 2009). At the same time study has shown that poor financial condition of a company does not mean deficiency of the intellectual capital (Tobin's $\mathrm{Q}<1$ ) and in parallel the company in a good financial condition has such capital enough (Tobin's $Q>1$ ). The only thing that could be said is that for the companies located in high risk business area the level of the Tobin's $\mathrm{Q}$ indicator is lower than average level for healthy companies. This leads to conclusion that it is good practice to compare the value of the Tobin's Q indicator of the company to average value in the industry or the whole economy. This information could be used to warn shareholders, investors and the company about the potential crisis, D. Appenzeller suggests that the growing intellectual capital is linked with lower risk of bankruptcy and vice versa. However it is not possible to determine exactly how the changes of intellectual capital value may have impact on this bankruptcy or its lack. This is due to the fact that the market value of the company does not depend only on the intellectual capital, but primarily on the stock market situation. In periods of economic recession, the market value of the company may decrease, which is not synonymous with a decrease the intellectual capital of the company.

The importance of non-tangible assets and intellectual capital measurement in predicting the market value of the company is also recognised by W. Wlodarczyk (Chairman of the Board GTECH Poland). In his point of view comprehensive system of measuring human capital (especially in terms of staff development and knowledge management) provides employees the maximum access to knowledge. Well prepared, trained, competent employee easily and efficiently communicate with customers, because better understand their needs. Excellent communication between the company and its customers significantly affects the organization condition, as reflected in business indicators (Kiszluk, 2014). For decades, organisations such as Financial Accounting Standards Board (FASB) created financial reporting standards, which requires to take into account shortterm material factors such as earnings, cash flow and profitability while in recent years there appears to be a trend towards using multiple forms of long term incentives and measures of value creation (Bashker, 2013). Also Dave Ulrich points out that recently investors have increased interest in non-tangible assets
MEASUREMENT OF HUMAN CAPITAL

Joanna Żarnik-Żuławska 
MEASUREMENT OF HUMAN CAPITAL

Joanna Żarnik-Żuławska such as strategy, brand, research and development, innovation, willingness to take risks and dynamics of a information flow.

Reasonable, long-term investors recognise importance a leadership in the organization. Research shows that $30 \%$ of the decisions related to financial investments were made dependent on the quality of leadership in the company. The high quality of leadership is treat as a crucial element to improve the overal all performance of the company and increase its market value. The interest of shareholders and investors moved on from the financial results of the company to non-tangible assets such as the leadership (Ulrich, 2015).

According to David Ulrich it is time for assessment of leadership in a more rigorous manner - through the eyes of investors, who are often determined to increase the company's market value more than managers. Leadership is not only the personal skills and abilities, but also the investments made to ensure the future leaders in the organisation. The literature suggests that assessment of leaders usually runs on two levels:

- individual (assessment of competence, key features of the leaders),

- organisational (refers to the concept of management by leaders, in the specific business conditions) (Church and Rotolo, 2013). These two areas together form the so-called Leadership Capital Index, which can be used by the investors to analyse their decisions and to increase the impact of HR managers on the intellectual capital value of the company (Ulrich, 2015). Therefore, the role of HR managers is increasing and the quality of their work affects the company's ability to develop and acquire new investors. The more reliable data on the human and intellectual capital the HR can provide, the better can be demonstrated values of the company to potential investors.

The report of Global Human Capital Trends 2016 prepared by Deloitte also indicates importance of leadership in the goodwill creation. The report was created on the basis of the study which was attended by more than 7 thousand respondents in 130 countries worldwide [7]. Figure 5 presents 10 most important human capital trends in 2016.

$89 \%$ respondents indicated that strengthen the leadership in their organizations will be a priority in coming months. The current model of leadership does not provide for the appropriate number of leaders to the needs of companies. The most important task for the $92 \%$ companies will be to increase the organisational capacity through the structures reorganisation. This means moving away from the traditional, functional models in towards the virtual, flexibile teams. 9 out of 10 companies admit that the structures reorganisation will be crucial for them in the coming months.

Trends in the human capital management presented in the Figure 5 indicate 


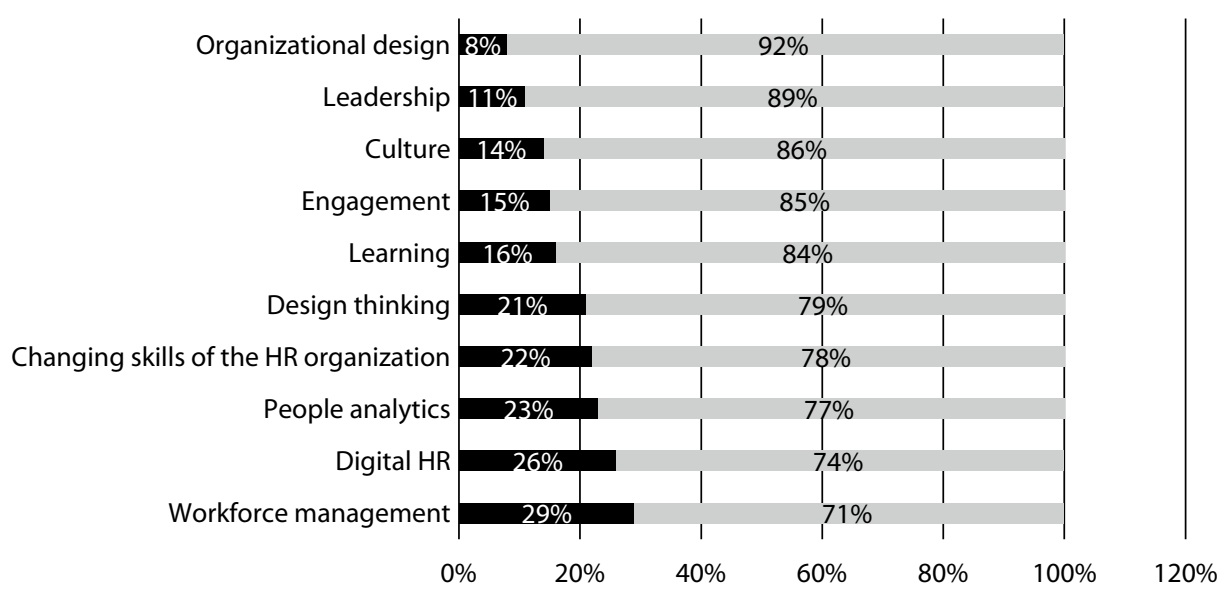

Somewhat/not importan Very important/important

leadership, structures reorganization and increasing productivity are likely to be used to predict the company's value and probably will be included in the reports sent to the shareholders and investors.

\section{Conclusion}

The company's market value does not always reflected the company's potential. Implementation of human capital measurement helps to pay attention to key elements for building the competitiveness on the market such as leadership, information flow etc. The more reliable data regarding intellectual and human capital can be provided, the easier is to gain the interest of potential investors and increase the company's market value. Therefore, in the nearest future greater emphasis on activities related to the development of methods for intellectual capital measuring might be observed.

\section{Notes}

[1] Forbes, Global 2000 World's Top Companies 2016 Ranking,. available at: http://www.forbes. com/global2000/list/\#header:marketValue_sortreverse:true (accessed 28 December 2016).

[2] Data on the Polish listed companies Dane GPW,. available at: https://www.gpw.pl/spolki_z_ indeksu_wig20 (accessed 28 December 2016).

[3] Brand Finance Global 500, The annual report on world's most valuable brands, February 2016, available at: http://brandfinance.com/images/upload/global_500_2016_for_print.pdf (accessed 28 December 2016).

[4] McGill, Partner, PwC, forward to Pensions and Lifetime Savings Association (formerly National Association of Pension Funds Ltd) report, Where is the workforce in corporate reporting? PLSA (formerly NAPF), June 2015 available at: https://integratedreporting.org/wp-content/ uploads/2015/12/CreatingValueHumanCapitalReporting_IIRC06_16.pdf
MEASUREMENT OF HUMAN CAPITAL

Joanna Żarnik-Żuławska

Figure 5. The 10 human capital trends ranked in order of importance

Source: Global Human Capital Trends 2016 The new organization: Different by design, Deloitte University

Press, www2. deloitte.com/content/ dam/Deloitte/ be/Documents/ human-capital/gxdup-global-humancapital-trends-2016.

pdf. 
MEASUREMENT OF HUMAN CAPITAL

Joanna Żarnik-Żuławska (accessed 29 December 2016).

[5] Guide on Measuring Human Capital, United Nations Economic Commission for Europe, January 2016, s. 32, available at: https://www.unece.org/fileadmin/DAM/stats/documents/ece/ces/2016/mtg/ HumanCapitalGuide_CES-Consult.pdf (accessed 30 December 2016).

[6] International Integrated Reporting Council ('the IIRC'), June 2016, available at: http://integratedreporting.org (accessed 29 December 2016).

[7] Global Human Capital Trends 2016 The new organization: Different by design, Deloitte University Press, available at: https://www2.deloitte.com/content/dam/Deloitte/be/Documents/humancapital/gx-dup-global-human-capital-trends-2016.pdf (accessed 30 December 2016).

\section{References}

Armstrong, M. (2007), Human Resource Management Practice, Kogan Page, London.

Appenzeller, D. (2009), Wartość kapitału intelektualnego firmy a prognozowanie upadtości, Prace Naukowe Uniwersytetu Ekonomicznego, Wrocław.

Becker, B. E., Huselid, M. A., Ulrich, D. (2013), Karta wyników zarządzania zasobami ludzkimi, Wolters Kluwer Business, Warszawa.

Bashker, D. B. (2013), How to use finance and accounting in HR (collection), FTPress, New Jersey.

Bontis, J., Fitzenz, J. (2002), "Intellectual capital ROI: A current map to human capital antecedents and consequences", Journal of Intellectual Capital, Vol. 3, pp. 223-243.

Church, A. H., Rotolo, T.C. (2013), "How are Top Companies assessing their highpotentials and senior executives, A Talent Management benchmark study", Consulting Psychology Journal: Practice and Research, Vol. 65 No. 3, pp. 199-223. DOI: http:// dx.doi.org/10.1037/a0034381

Edvinsson, L., Sullivan, P. (1996), "Developing a Model for Managing Intellectual Capital”, European Management Journal, Vol. 14 No. 4, pp. 356-364. DOI: http://dx.doi. org/10.1016/0263-2373(96)00022-9

Jarugowa, A., Fijałkowska, J. (2002), Rachunkowość i zarządzanie kapitatem intelektualnym, Ośrodek Doradztwa i Doskonalenia Kadr Sp. z o.o., Gdańsk.

Kaminska, G., Boiarova, A., Germanchuk, O. (2014), "Intelektual Capotal in the Enterprise Value Formation", Journal of Financial Management and Accounting, Vol. 2 No. 1, pp. 47-58.

Kiszluk, G. (2014), "Dla nas płeć nie ma znaczenia", wywiad z Wojciechem Włodarczykiem, prezesem zarządu GTECH Poland, Brief, nr 3/179, Warszawa.

Lipka, A. (2010), Wycena kapitału ludzkiego organizacji - problemy metodyczne, Prace Naukowe Uniwersytetu Ekonomicznego w Katowicach, Katowice.

Liu, G. (2014), Measuring the Stock of Human Capital for International and Intertemporal Comparisons, University of Chicago Press, Chicago.

Mouritsen, J., Larsen, H. T. (2001), Valuing the future: intellectual capital supplements at Skandia Copenhagen Business School, Frederiksberg, Denmark.

Nakamura, L. I. (2000), "Economics and the New Economy: The invisible Hand Meets Creative Destruction (Federal Reserve Bank of Philadelphia)", Business Review, July/ August, pp. 15-30.

Oxley, L., Thinh, L., Gibson, J. (2008), "Measuring human capital alternative methods and international evidence", The Korean Economic Review, Vol. 24 No. 2, pp.283-338. 
Rutkowska, A. (2012), Istota kapitału ludzkiego i wybrane metody jego zarzadzania, Zarządzanie i Finanse, Gdańsk.

Sierpińska, M. (2004), Controling Funkcyjny w przedsiębiorstwie, Oficyna Ekonomiczna, Kraków.

MEASUREMENT

OF HUMAN

CAPITAL

Joanna Żarnik-Żuławska

Ulrich, D. (2015), The Leadership Capital Index Realizing the Market Value of Leadership, Berrett-Koehler Publishers, Oakland, California.

Wachowiak, P. (2005), Pomiar kapitału intelektualnego przedsiębiorstwa, SGH, Warszawa.

Ward, A. (2008), "Ac-Count-able HR", Human Resource Management International Digest, Vol. 16 No. 3, pp. 11-13. 